\title{
Guidelines may boost gene therapy in Japan
}

Tokyo. Gene therapy in Japan took a further step forward this week with the publication of guidelines for the manufacture and testing of therapeutic products by the Ministry of Health and Welfare (MHW) that are expected to pave the way for greater activity.

The new guidelines clarify the vectors, methods of administration, testing and certification needed for approval of products used in gene therapy, and are virtually identical to those already published by the US Food and Drug Administration (FDA).

Gene therapy has been slow to take off in Japan. Only one clinical trial has begun so far, and the pharmaceutical companies none particularly large by world standards - have been slow to enter the field.

According to Yoshiro Ohtaki of Japan Associated Finance Corporation (JAFCO), a venture capital company that is backing various biotechnology initiatives, this is partly due to the lack of qualified personnel for controlling vector quality and other tasks specific to gene therapy. But another factor has been the lack of official guidelines for companies to follow in the formulation of therapeutics, with the result that companies have not known what data was required.

The delays experienced by Japan's first gene therapy trial, which started in August at Hokkaido University in northern Japan (see Nature 376, 628; 1995), were caused by the fact that the health ministry had not initially been supplied with safety data on the viral vectors by the manufacturers, Genetic Therapy Inc., of Gaithersburg, Maryland.

The Hokkaido trial, which has involved treatment of a four-year-old boy suffering from adenosine deaminase (ADA) deficien$\mathrm{cy}$, is proceeding successfully. It will not lead

\section{Livermore loses supercomputers to Berkeley}

San Francisco. Lawrence Livermore National Laboratory (LLNL) in California has lost its \$45-million supercomputing centre to its northerly neighbour, Lawrence Berkeley Laboratory, after a competitive bid. The National Energy Research Supercomputer Center (NERSC), housed at Livermore for 22 years, employs 110 people in unclassified energy research and manages three supercomputers, including a \$25-million Cray C-90.

US laboratories have been under considerable pressure to reduce spending and streamline their activities. They have been asked to find more opportunities to cooperate on projects and share resources. Livermore scientists will continue to use the NERSC through high-speed links.

The Department of Energy (DoE) said the laboratory's location at Berkeley will allow integration of non-classified computing with research programmes in energy science, chemistry, high-energy and nuclear to a commercial therapy, as there are relatively few sufferers in Japan. But its success has helped the broader prospects for commercial gene therapy in Japan by demonstrating the efficacy of the treatment to a sceptical pharmaceutical industry, according to observers such as Mitsuru Miyata, chief editor of Nikkei Biotechnology.

Japan's first clinical trials of a potentially commercial gene therapy will probably begin early next year when Midori Juji (Green Cross Corporation), an Osaka-based manufacturer of blood products, will begin testing a treatment for HIV infection using viral vectors supplied by the US company Chiron-Viagene.

The Japanese company, which will carry out its research in association with Kumamoto University Hospital in Kyushu, has informally told both the health ministry and the Ministry of Education, Sport, Science and Culture (Monbusho) of its plans. But it has yet to make an official
London. The United States and Japan have agreed to set up an international panel to review the current and future activities of the Radiation Effects Research Foundation (RERF), the body set up in Hiroshima to study the long-term effects of the atomic bombs dropped on Hiroshima and Nagasaki at the end of the Second World War.

The panel will be chaired by Roger Clarke, chairman of the International Commission on Radiological Protection and director of the UK National Radiological Protection Board (NRPB). Its eight mem-

physics, material science and genomics. It plans to complete the move by next April.

Berkeley's proposal had convinced DoE that it could manage the computer laboratory more efficiently and with more potential for collaboration. Both laboratories aimed to cut costs by about 20 per cent.

Staff members at Livermore expressed their disappointment with a "for rent" sign on the door of the centre. But Bruce Tarter, director of LLNL, played down the importance of the supercomputers' departure. He has long argued that supercomputing can still grow at the laboratory, even without NERSC. A new LLNL team, made up of people from Livermore Computing (LC) and NERSC, will reorganize computing for both classified and unclassified research at the laboratory.

NERSC was created in 1974 to serve the national magnetic fusion energy programme. According to LLNL, it currently serves about 4,500 users. Sally Lehrman

application for approval for the research.

Although the new guidelines will hasten the application of gene therapy technology in Japan, formidable barriers remain to its indigenous development. Of the five groups planning clinical trials of such therapy at universities in Nagoya, Nigatta and Tokyo, four will rely on vectors supplied by US companies, says Kenzaburo Tani of Tokyo University's Institute of Medical Science.

Tani, whose group plans to test a gene therapy for renal cell cancer, says that although Japan's pharmaceutical companies are reluctant to pay the royalties demanded for the use of foreign technology, they are also reluctant to support the basic research required to develop their own technologies. In contrast to the United States, where the need for high risk research is met by start-up companies financed by venture capital, the continuing lack of such companies in Japan appears to be leaving its own industry at a disadvantage.

Stephen Barker

\section{Review for radiation effects research}

bers - none of whom have previously been involved in RERF's activities - include two medical researchers from Japan, two from the United States, and one each from Argentina, Australia, Germany and the United Kingdom.

The decision to set up a review panel follows the protests that greeted plans announced by the US Department of Energy (DoE) at the beginning of the year to remove administrative and scientific responsibility for the RERF from the National Academy of Sciences, which had carried out this role since 1947. Apparently backtracking on earlier claims that the management contract was being withdrawn from the academy partly because of excessive secrecy surrounding some of RERF's research, Hazel O'Leary, Secretary for Energy, subsequently announced that the academy's contract was to be extended for a further two years (see Nature 375, 709; 1995).

At the same time, the department said that it had accepted a proposal from RERF's Science Council that any restructuring of the foundation's work should be deferred until it had been reviewed by a team of external experts. The panel that has now been set up is expected to identify how the foundation can use its data and expertise to contribute to radiation research worldwide.

The first meeting of the panel, whose broad remit is "to strengthen and enhance the scientific contributions of RERF", will take place in February, and will include visits to both Hiroshima and Nagasaki. Technical support will be provided by the NRPB, and a final report is due by July 1996 . 